\section{The British Institute of Archæology, Ankara: Mr. Seton Lloyd}

Mr. Seton Lloyd, who (as announced in Nature of August 14, p. 250) has been elected to the directorship of the recently founded British Institute of Archæology in Ankara, started his career as architectural assistant to Sir Edwin Lutyens, and gained his early archæological experience in Egypt during the late 'twenties. During 1930-37 he worked under Dr. Henri Frankfort, as field supervisor to the Iraq Expedition of the Chicago Oriental Institute, and there gained an exceptionally detailed knowledge of mound-excavation on a wide variety of Mesopotamian sites. During this period he had the satisfaction of recovering many now famous art treasures from the rich Sumerian temples of Tell Asmar and Tell Ajrab. Next came two seasons with the Neilson Expedition under Prof. J. Garstang at Mersin in Turkey, where a stratified excavation of extreme complexity gave full scope to his particular talent. Since 1939, as technical adviser to the Directorate of Antiquities in the Government of Iraq, he has been indirectly responsible for a succession of astonishingly successful excavations, which have not only preserved the continuity of archæological discovery, but also raised his Department from a mere administrative service to a unique position as a research institution. Indeed, it would be difficult to over-estimate the debt which Mesopotamian archæology already owes to Mr. Lloyd's technique and the new generation of Iraqi excavators to his guidance. His name is now coupled with those of Mallowan and Woolley as one of the most gifted and successful excavators of our age. On him devolves the task of training those of the coming generation, and it could not be in better hands. His publications show him to be a good all-round archæologist and good artist, with a scholarly as well as a scientific outlook. The new Institute thus makes an auspicious start.

\section{Botany in Nigeria :}

\section{Prof. F. W. Sansome}

The new University College in Nigeria is fortunate to have secured Dr. F. W. Sansome as its first professor of botany. Dr. Sansome received his undergraduate training in Edinburgh as an agriculturist. Upon this foundation he added, at first in Glasgow and later at the John Innes Horticultural Institution, a thorough training in botany and genetics. At this time Dr. Sansome carried out important work on tetraploidy in tomatoes, and published (with Dr. Philp) "Recent Advances in Plant Genetics", which rapidly ran through two editions. He then became senior lecturer in the Botany Department in the University of Manchester, and assistant director of the Experimental Grounds, with responsibilities in horticultural botany and genetics. He devoted his energy, with great success, to the building up of facilities for horticultural research, and the Jodrell Bank Station owes its efficiency to Dr. Sansome's work. Dr. Sansome's infectious enthusiasm has endeared him to horticulturists and students in the north of England, and his wisdom and wit and generosity are greatly appreciated by his colleagues. The good wishes of professional botanists and a large general public will accompany him on his new venture. It is a pleasure to know that his wife, who is distinguished for her research on cytology, is to be a research fellow in Ibadan. and will continue her work there.

\section{Veterinary Science in Bristol:}

\section{Prof. F. Blakemore}

IN 1943 the Committee on Veterinary Education, of which Dr. T. Loveday was chairman, recommended. that a new school of veterinary science should be established in the University of Bristol. With the concurrence of the Ministry of Agriculture and Fisheries and of the University Grants Committee, the University has undertaken to carry out this recommendation. Plans are far advanced for the additional buildings required, and the small estate of Langford is available as a field station. It is pro. posed to admit students to the first year of study in the autumn of 1949. The University has recently appointed, as its first professor of veterinary medicine, Mr. F. Blakemore, who is at present superintending veterinary investigation officer for England and Wales. Mr. Blakemore received his veterinary education at the Universities of Liverpool and Manchester. After some experience in practice he served as veterinary officer for the county of Glamorgan, and as veterinary investigation officer for the Eastern Provinces. In 1946 he was appointed to the post he now relinquishes. He has been responsible for the teaching of general hygiene in the University of Cambridge. Mr. Blakemore has carried out extensive work on fowl paralysis and on various diseases of lambs, calves and pigs. He was the first to identify fluorine poisoning of stock in Great Britain and has traced its relation to industry. Recently he has been engaged in the study of mineral deficiency diseases in cattle.

\section{Marin Mersenne (1588-1648)}

ON September 1 occurs the tercentenary of the death of the French ecclesiast, mathematician and philosopher, Marin Mersenne, whose correspondence with his contemporaries, published in 1933-37, sheds much light on the history of physical science. Born on September 8, 1588, at La Souitiède, Sarthe, he was educated at the Jesuit College at La Flêche, where for a short time he had Descartes-eight years his junior-as a school-fellow. From La Flêche, Mersenne went to Paris to study at the Sorbonne, and about 1616 entered the religious order of Minim Friars, an offshoot of the Franciscans. From 1616 until 1619 he was professor at the College of Nevers and thence onwards was superior of the Convent of his Order in Paris. He travelled into Germany, Holland and Italy, translated Galileo's "Mechanics", and held small gatherings of mathematicians and the like in his room in the Convent, thus anticipating the inauguration of the Royal Academy of Sciences.

\section{Auguste Henri Forel}

NEURologist, psychiatrist, entomologist, eugenist, temperance and penal reform advocate, Auguste Henri Forel was born a century ago, on September 1, 1848, at Morges, Canton Vaud, in Switzerland. His childhood studies of ants culminated in the publication, at the age of twenty-six, of "Les Fourmis de la Suisse", of which Darwin confessed that seldom in his life had he been more interested by any book. Studying medicine at Zurich, Forel specialized in psychiatry and was appointed professor of psychiatry in the University and director of the Insane Hospital. The more important works of this indefatigable and versatile man include "Der Hypnotismus und die Suggestive Psychotherapie" (1889), "Hygiene der Nerven und des Geistes" (1903) and "Die Sexuelle 